\author{
삼상유동층 공정에서 수력학적 Similarity 해석 \\ 임 호* · 임현오** · 진해룡* · 임대호* · 강 용***,† \\ *충남대학교 화학공학과 \\ 305-764 대전시 유성구 궁동 220 \\ **충남대학교 녹색에너지 전문대학원 \\ 305-764 대전시 유성구 궁동 220 \\ (2011년 3월 14일 접수, 2011년 4월 13일 채택)
}

\title{
Analysis of Hydrodynamic Similarity in Three-Phase Fluidized Bed Processes
}

\author{
Ho Lim*, Hyun Oh Lim**, Hae Ryoung Jin*, Dae Ho Lim* and Yong Kang***,† \\ *Department of Chemical Engineering, Chungnam National University, 220 Gung-dong, Yuseong-gu, Daejeon 305-764, Korea \\ **Graduate School of Green Energy Technology, Chungnam National University, 220 Gung-dong, Yuseong-gu, Daejeon 305-764, Korea \\ (Received 14 March 2011; accepted 13 April 2011)
}

\begin{abstract}
요 약
삼상유동층에서 수력학적 유사성을 규모인자(scaling factor)를 이용하여 해석하였다. 규모인자는 직경이 다른 두 종 류의 삼상유동층간의 기체, 액체, 그리고 고체입자의 체류량과 단위면적당 유효부피흐름속도를 기준으로 정의하였다. 두 종류 삼상유동층의 직경은 각각 $0.102 \mathrm{~m}$ 와 $0.152 \mathrm{~m}$ 이었다. 여과된 압축공기, 물 그리고 밀도가 $2,500 \mathrm{~kg} / \mathrm{m}^{3}$ 인 유 리구슬을 각각 기체, 액체 그리고 유동고체입자로 사용하였다. 각 삼상유동층에서 각 상들의 체류량은 정압강하법에의 해 결정하였다. 기체 및 액체의 유속 그리고 고체유동입자의 크기가 각 상들을 기준으로한 규모인자와 유효부피흐름 속도를 기준으로한 규모인자에 미치는 영향을 검토하였다. 직경이 다른 두 삼상유동층에서 기체 체류량의 편차는 기 체와 액체의 유속이 증가함에 따라 감소하였으나 유동입자의 크기가 증가함에 따라 증가하였다. 직경이 다른 두 종류 삼상유동층에서 액체 체류량 편차는 기체와 액체 그리고 고체유동입자의 크기가 증가함에 따라 감소하였다. 두 종류 삼상유동층에서 고체입자 체류량 편차는 기체유속과 유동입자의 크기가 증가함에 따라 증가하였으나 액체의 유속이 증가함에 따라 감소하였다. 직경이 다른 두 종류 삼상유동층에서 유효부피흐름속도를 매개로 한 규모인자는 기체유속 과 유동입자의 크기가 증가함에 따라 감소하였으나 액체의 유속이 증가함에 따라 증가하였다. 본 연구에서 정의된 규 모인자는 삼상유동층 공정의 수력학적 유사성을 해석하는데 효과적으로 사용될 수 있었다.
\end{abstract}

\begin{abstract}
Hydrodynamic similarity was analyzed by employing scaling factor in three phase fluidized beds. The scaling factor was defined based on the holdups of gas, liquid and solid particles and effectivity volumetric flux of fluids between the two kinds of fluidized beds with different column diameter. The column diameter of one was $0.102 \mathrm{~m}$ and that of the other was $0.152 \mathrm{~m}$. Filtered compressed air, tap water and glass bead of which density was $2,500 \mathrm{~kg} / \mathrm{m}^{3}$ were used as gas, liquid and solid phases, respectively. The individual phase holdups in three phase fluidized beds were determined by means of static pressure drop method. Effects of gas and liquid velocities and particle size on the scaling factors based on the holdups of each phase and effective volumetric flux of fluids were examined. The deviation of gas holdup between the two kinds of three phase fluidized beds decreased with increasing gas or liquid velocity but increased with increasing fluidized particle size. The deviation of liquid holdup between the two fluidized beds decreased with increasing gas or liquid velocity or size of fluidized solid particles. The deviation of solid holdup between the two fluidized beds increased with increasing gas velocity or particle size, however, decreased with increasing liquid velocity. The deviation of effective volumetric flux of fluids between the two fluidized beds decreased with increasing gas velocity or particle size, but increased with increasing liquid velocity. The scaling factor, which was defined in this study, could be effectively used to analyze the hydrodynamic similarity in three phase fluidized processes.
\end{abstract}

Key words: ThreePhase, Fluidized Bed, Similarty, Hydrodynamic, Scale Factor

\footnotetext{
${ }^{\dagger}$ To whom correspondence should be addressed.

E-mail: kangyong@cnu.ac.kr
} 


\section{1. 서 론}

21 세기 산업의 다양화와 첨단 산업기술의 발전에 따라 효율적인 첨단공정들이 개발되고 다양한 소재들이 개발되고 있다. 다양한 소 재의 개발과 소재의 고 기능화 그리고 반응공정의 처리능력향상과 효율증진을 위하여 다상(multiphase)들 간의 접촉과 반응을 수행하 는 불균일계 반응공정은 거의 필수적이라 할 수 있다. 뿐만 아니라 다상들간의 불균일계 반응도 반응조건이 일반적인 정상상태 (steady state)가 아닌 비정상상태의 특별한 조건이나 높은 에너지 의 상태를 필요로 하는 활성화 상태에서의 반응공정들이 주목을 받 게 되고 있다. 이들 다상들간의 불균일계 반응을 효과적으로 수행 하기 위하여 각 반응들의 특성에 맞는 반응공정의 개발이 매우 중 요하다 하겠다.

다 기능의 효율적인 다상흐름 반응공정으로 대표적인 공정인 삼 상유동층 공정은 기체, 액체, 고체상 등의 접촉과 반응이 매우 효 율적이며, 연속공정이 가능하여 생산 효율이 매우 높기 때문에 화 학반응공정, 생물공정, 석유화학공정, 환경공학공정, 신재생에너지 공정 등에 매우 많이 적용되고 있다[1-6]. 그러나, 이들 공정의 공 업화를 위하여 scale-up 기술과 설계기술이 필수적인데 삼상유동 층 공정은 다상의 접촉과 흐름공정이 동력학적계(dynamic system) 를 이루고 있어서 정적인계(static system)에 비하여 scale-up 기술 에 대한 개발이 매우 부진하여 왔다. 삼상유동층 공정의 scale-up 이나 설계를 위해서 국내·외적으로 연구는 진행되고 있으나 주로 실험변수나 조작변수들과 목적함수들의 상관성 고찰에 따른 상관 식 도출이나 조작변수들의 차원해석에 의한 무차원군의 도출과 계 의 주요제어인자들로 구성된 무차원군 상호간의 상관성고찰과 상 관식도출이 주를 이루고 있다[3-7].

한편, 삼상유동층 공정과 같은 다상들간의 접촉이 일어나는 불균 일계공정의 해석에는 결정론적 방법(deterministic method)에 근거한 Navier-Stokes식과 같은 식들의 해석이 매우 어려우므로 통계학적 방 법들이 응용되고 적용됨으로써 매우 효과적으로 계가 설명되고 해석 되기도 한다[8-13]. 이는 삼상유동층 공정과 같은 동력학적계의 거동 과 특성은 정적인계와 비교하여 통계학적인 요소들을 많이 내포하고 있기 때문이다. 즉, 결정론적 방법에 의한 연역적 접근방법보다는 계의 특성에 근거한 귀납적 접근방법이 설득력을 얻고 있다.

본 연구에서는 삼상유동층 공정의 scale-up 기술 개발의 일환으로 유동층 공정의 직경 변화가 기체, 액체 및 고체 입자의 체류량과 공 정내부에서 유체의 유효부피흐름속도(effective volumetric flux of fluid)에 근거한 규모인자(scale factor)에 미치는 영향을 고찰하였다. 즉, 실험변수인 기체 및 액체의 유속 그리고 유동고체입자의 크기가 삼상유동층 공정의 직경이 변화할 때 규모인자에 미치는 영향을 검 토하였다.

\section{2. 실 험}

본 연구의 실험에서는 Fig. 1 에서 볼 수 있듯이 내경이 $0.105 \mathrm{~m}$ 및 $0.152 \mathrm{~m}$ 이고 높이가 각각 $2.5 \mathrm{~m}$ 인 아크릴 관으로 만들어진 삼상유 동층 공정을 사용하였다[13,14]. 각 삼상유동층 공정의 수력학적유 사성에 기초한 규모인자(scale factor)를 검토하기 위해 조작변수로는 기체 $(0.01 \sim 0.07 \mathrm{~m} / \mathrm{s})$ 및 액체 $(0.01 \sim 0.07 \mathrm{~m} / \mathrm{s})$ 의 유속 그리고 고체유 동입자의 크기 $\left(0.5 \sim 3.0 \times 10^{-3} \mathrm{~m}\right)$ 등을 선택하였다. 기체로는 여과된

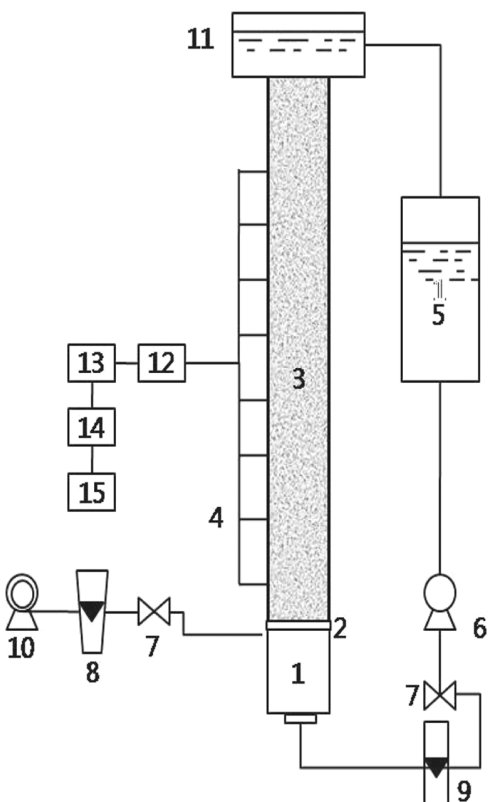

Fig. 1. Experimental apparatus
1. Calming section
2. Gas distributor
3. Main column
4. Pressure tap
5. Liquid reservior
6. Pump
7. Valve
8. Gas flowmeter
9. Liquid flowmeter
10. Air compressor
11. Weir
12. Pressure sensor
13. Data Acquisition system
14. A/D converter
15. Computer

후 유속과 압력이 조절되는 압축공기를 사용하였으며 연속상인 액상 으로는 물을 그리고 고체 유동 입자로는 밀도가 $2,500 \mathrm{~kg} / \mathrm{m}^{3}$ 인 구형 의 유리입자를 사용하였다. 유동층 내부에 투입되는 기체와 액체의 균일한 분포를 위해 기체와 액체가 동일한 면에서 투입되는 다공판 형태의 기체-액체 분산판을 사용하였다 $[13,14]$. 유동층의 축 방향 압 력강하를 측정하기 위하여 유동층의 액체-기체 분산판으로부터 $20 \mathrm{~cm}$ 떨어진 위치에서 $20 \mathrm{~cm}$ 간격으로 8 개의 압력 탭을 설치하여 유동층의 축 방향 압력변화를 측정하였다. 삼상 유동층의 축 방향 각 위치에서 압력변동 신호는 일정한 실험조건에서 압력센서(Sensys)로 측정하였으며 이 신호는 압력 변환기에 의해 볼트-시간의 신호로 바 뀌어 증폭기와 필터 그리고 $\mathrm{A} / \mathrm{D}$ 변환기를 거쳐 디지털 신호로 변환 시켜 데이터획득장치(data acquisition system, DT-2805 Lab Card, DT-VEE software)를 사용하여 PC에 입력시켜 저장한 후 Off-line Process로 통계적 처리를 하였다. 압력신호의 Sample 측정은 $500 \mathrm{~Hz}$ 로 하였으며 시료의 길이는 10,000 이상으로 하여 각 실험조건에서 충분히 압력요동의 특성을 분석할 수 있도록 하였다[12,15].

삼상 유동층에서 기체, 액체 및 고체입자의 체류량은 정압강하법 (Static pressure drop method)에 의해 결정하였다[1-4]. 즉, 삼상 유동 층이 일정한 기체와 액체의 유속조건에서 정상상태로 운전될 때, 유 동층 내부의 일정 영역에서의 정압강하를 측정하여 식 (1) (3)을 사 용하여 각 상들의 체류량을 결정하였다.

$$
\begin{aligned}
& \varepsilon_{G}+\varepsilon_{L}+\varepsilon_{S}=1.0 \\
& \Delta \mathrm{P} / \Delta \mathrm{L}=\left(\rho_{\mathrm{G}} \varepsilon_{\mathrm{G}}+\rho_{\mathrm{L}} \varepsilon_{\mathrm{L}}+\rho_{\mathrm{S}} \varepsilon_{\mathrm{S}}\right) \mathrm{g}
\end{aligned}
$$$$
\varepsilon_{\mathrm{S}}=\mathrm{W} / \mathrm{SL} \rho_{\mathrm{S}}
$$ 


\section{3. 결과 및 고찰}

3-1. 기체, 액체, 고체 체류량 기준의 규모인자(Scale factor) 삼상유동층을 구성하는 세가지상의 체류량 특성은 기체나 액체 등 의 불균일계 반응물이나 촉매입자들 간의 반응시간과 농도의 결정에 직결되므로 삼상유동층 반응기의 설계나 scale-up에 필수적인 요소 가 된다[16-19]. 따라서, 본 연구에서는 각 상의 체류량을 삼상유동 층 공정의 scale-up에 필요한 규모인자(scale factor)의 매개대상으로 선정하였다. 삼상유동층에서 기체의 유속이 직경이 다른 두 삼상유 동층의 기체 체류량에 미치는 영향을 Fig. 2에 나타내었다. Fig. 2 (A), (B)에서 볼 수 있듯이 기체의 유속이 증가함에 따라 유동층 내 부 기체 체류량은 증가하나 직경이 다른 두 유동층간의 기체 체류량 차이는 감소함을 알 수 있다. 삼상유동층에서 분산상의 유체로 존재 하는 기체의 체류량을 매개로 한 유동층 설계에 필요한 규모인자를 얻기 위해 식 (4)와 같은 관계식을 구성하였다.

$$
\frac{\varepsilon_{G 2}}{\varepsilon_{G 1}}=\mathrm{A}_{G}\left(\frac{\mathrm{D}_{2}}{\mathrm{D}_{1}}\right)^{D_{F G}}
$$

여기서, $\mathrm{A}_{G}$ 는 비례상수이고 $\mathrm{D}_{F G}$ 는 기체 체류량을 매개로 한 규모 인자를 나타낸다.

직경이 $0.102 \mathrm{~m}$ 와 $0.152 \mathrm{~m}$ 의 두 종류의 삼상유동층에서 얻은 기 체 체류량의 비와 유동층 직경비의 자료를 이용하여 식 (4)에 의해 상수 $\mathrm{A}_{G}$ 와 규모인자 $\mathrm{D}_{F G}$ 의 값을 결정하였다. 이들 값의 결정은 일 정한 운전조건에서 측정된 자료의 시료크기(sample length)를 5가지 로 변화시켜서 얻은 자료의 오차한계가 $3 \%$ 이내가 되는 값으로 결 정하였다. 삼상유동층 공정에서 식 (4)에 의해 얻은 규모인자의 값을 운전변수인 기체의 유속변화에 따라 Fig. 3에 나타내었다. Fig. 3에

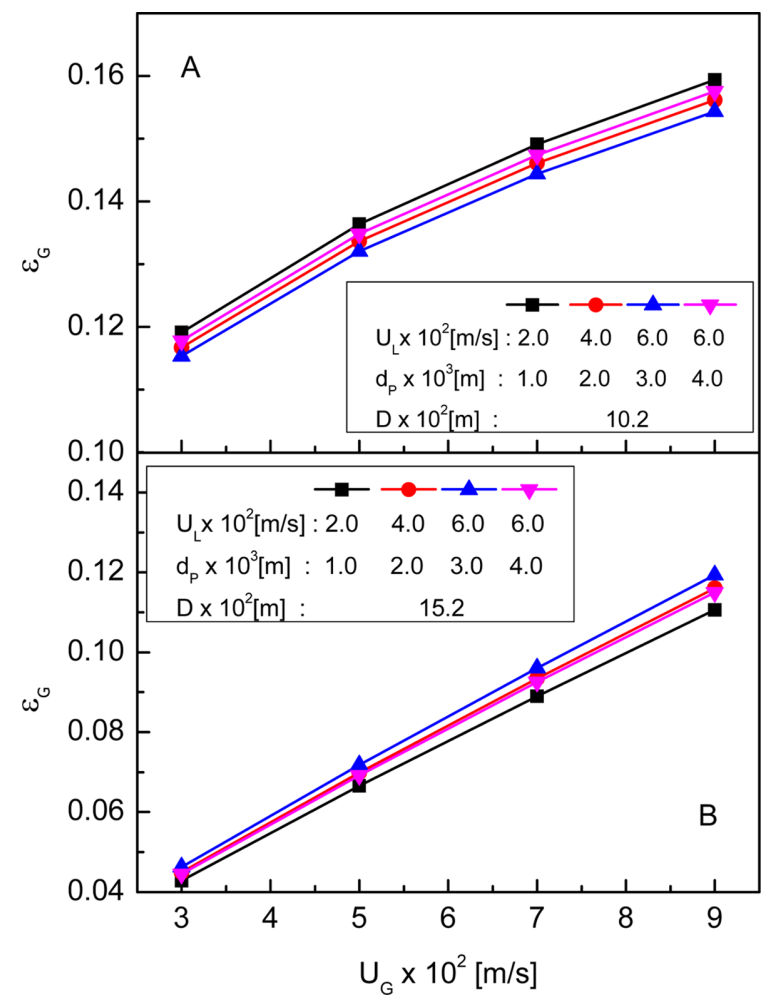

Fig. 2. Effects of gas velocity on the gas holdup in three phase fluidized beds.

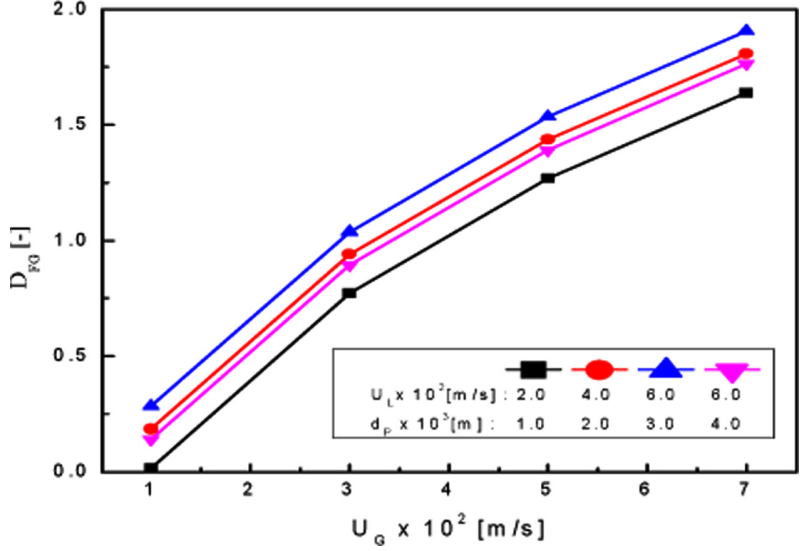

Fig. 3. Effects of gas velocity on the scale factor, $D_{F G}$, based on the gas holdup in three phase fluidized beds.

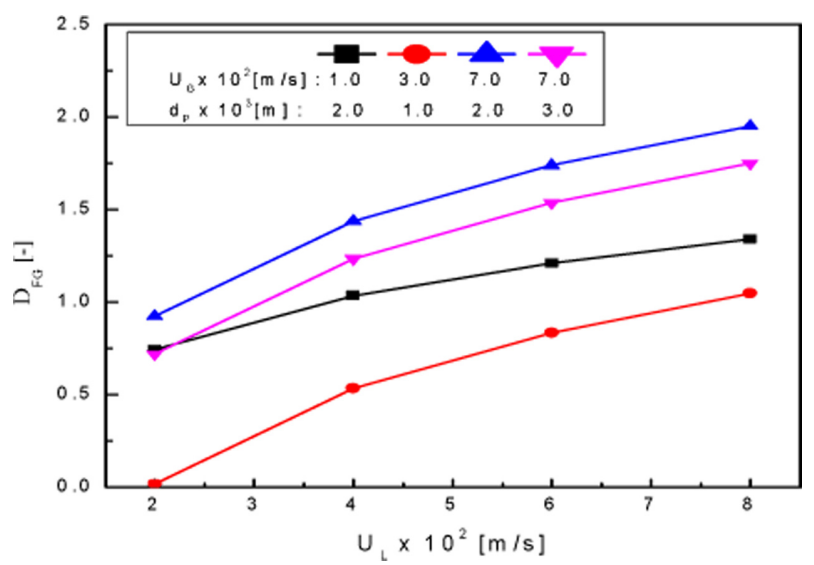

Fig. 4. Effects of liquid velocity on the scale factor, $D_{F G}$, based on the gas holdup in three phase fluidized beds.

서 볼 수 있듯이 규모인자인 $\mathrm{D}_{F G}$ 의 값은 기체의 유속이 증가함에 따 라 증가하였다. 이는 식 (4)의 좌변 값이 1 보다 작은 것으로 보아 기 체의 유속이 증가함에 따라 유동층의 직경변화가 유동층 내부에 존 재하는 기체 체류량의 변화에 미치는 영향이 1 에 가까워짐을 의미하 므로 기체 체류량의 편차가 감소함을 나타낸다. 즉, Fig. 2에서 기체 유속의 증가에 따라 직경이 다른 두 종류 유동층간의 기체 체류량의 편차가 감소함을 수식으로 나타낸 것임을 알 수 있다. 삼상유동층 공 정에서 액체의 유속이 규모인자 $\mathrm{D}_{F G}$ 에 미치는 영향은 Fig. 4에 나타 내었다. Fig. 4에서 볼 수 있듯이 $\mathrm{D}_{F G}$ 값은 액체유속이 증가함에 따 라 증가하였다. 이는 액체의 유속이 증가함에 따라 직경이 다른 두 종류 유동층의 기체 체류량 편차가 감소하는 것을 나타낸다. 삼상유 동층 공정에서 고체유동입자의 크기가 규모인자 $\mathrm{D}_{F G}$ 에 미치는 영향 을 Fig. 5 에 나타내었는데, 규모인자 $\mathrm{D}_{F G}$ 값은 고체유동입자의 크기 가 증가함에 따라 감소하였다. 이는 유동입자의 크기가 증가함에 따 라 직경이 다른 두 종류 유동층의 기체 체류량 편차가 증가함을 나 타낸다. 이와 같이 삼상유동층 공정에서 규모인자 $\mathrm{D}_{F G}$ 는 기체유속, 액체의 유속 그리고 고체유동입자의 크기에 따라 변화하므로 규모인 자 $\mathrm{D}_{F G}$ 값을 이들 세 변수의 상관식으로 식 (5)와 같이 나타낼 수 있 었다. 식 (5)의 상관계수는 0.84이었다. 한편, 식 (4)에서 상수 $\mathrm{A}_{G}$ 값 은 기체 및 액체의 유속 그리고 유동고체입자의 크기가 변화하여도 일정한 상수값 0.39 를 나타내었다. 


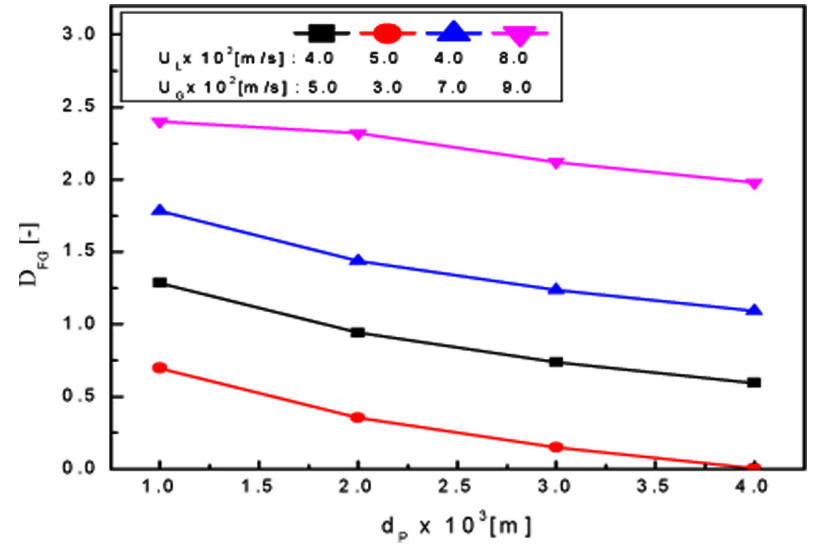

Fig. 5. Effects of particle size on the scale factor, $D_{F G}$, based on the gas holdup in three phase fluidized beds.

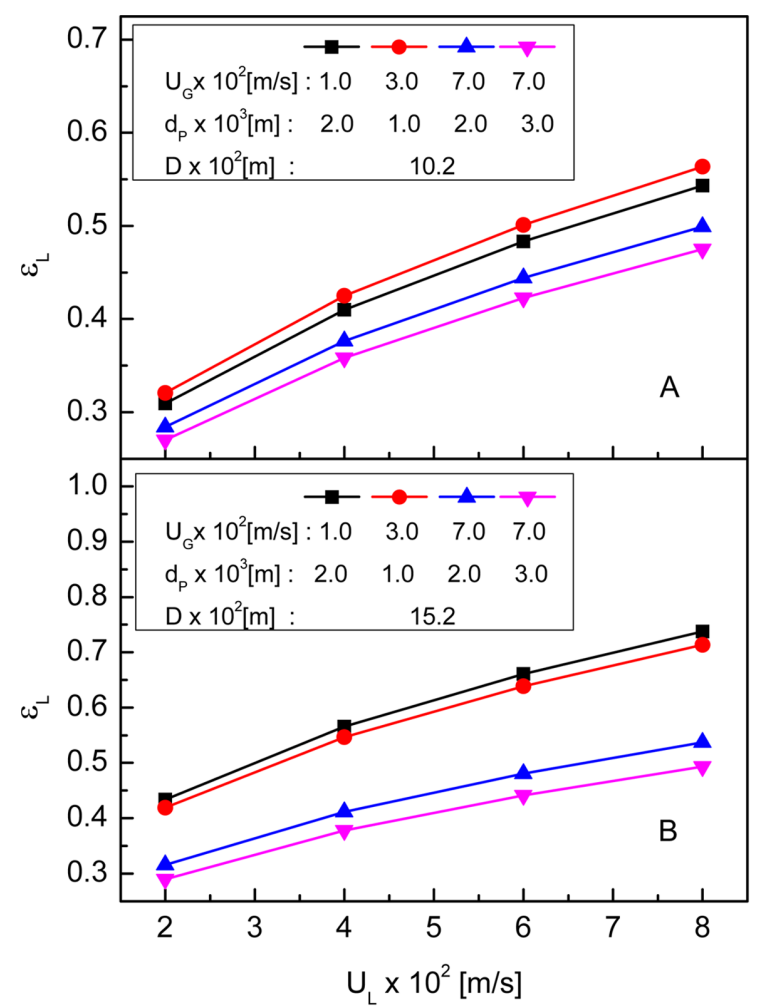

Fig. 6. Effects of liquid velocity on the liquid holdup in three phase fluidized beds.

$$
\mathrm{D}_{\mathrm{FG}}=3.19 \mathrm{U}_{G}^{0.87} \mathrm{U}_{L}^{0.91} \mathrm{~d}_{P}^{-0.35}
$$

삼상유동층에서 액체의유속이 연속 액상의 체류량에 미치는 영향을 Fig. 6에 나타내었다. Fig. 6(A), (B)에서 액체유속이 증가함에 따라 액체의 체류량은 증가하였으며, 직경이 다른 두 종류 유동층의 액체 체류량 편차는 점점 감소하였다. 이와 같은 현상을 수식으로 나타내 기 위하여 액체의 체류량을 매개로한 규모인자의 관계식을 식(4)와 유사하게 식 (6)과 같이 구성하였다.

$\frac{\varepsilon_{L 2}}{\varepsilon_{L 1}}=\mathrm{A}_{L}\left(\frac{\mathrm{D}_{2}}{\mathrm{D}_{1}}\right)^{D_{F L}}$

삼상유동층 공정에서 기체유속의 변화가 액체 체류량을 매개로 한

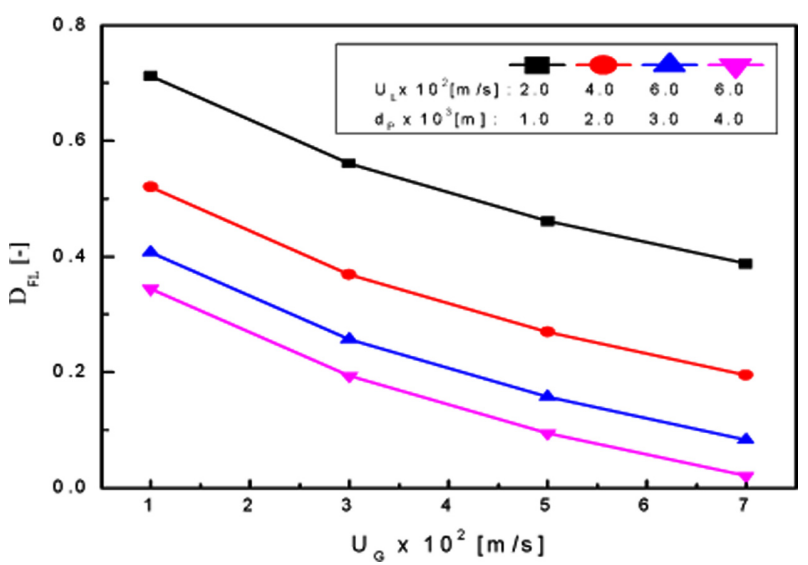

Fig. 7. Effects of gas velocity on the scale factor, $D_{F L}$, based on the liquid holdup in three phase fluidized beds.

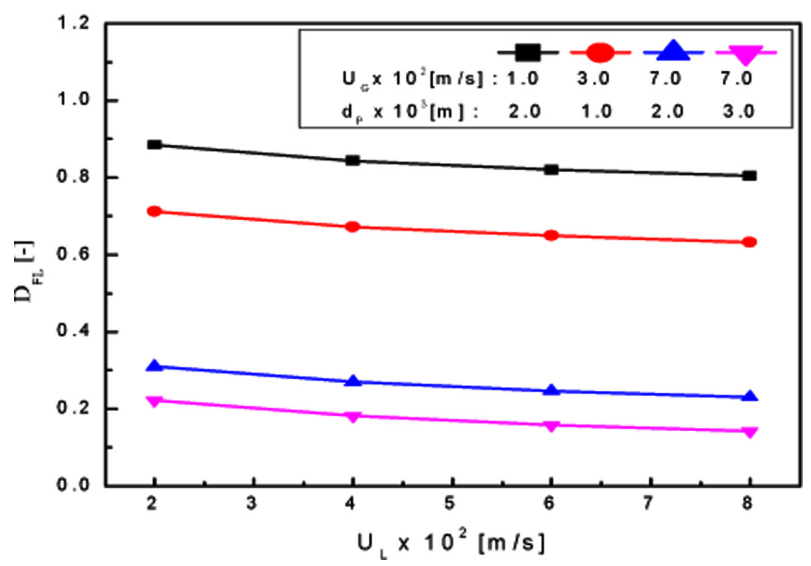

Fig. 8. Effects of liquid velocity on the scale factor, $D_{F L}$, based on the liquid holdup in three phase fluidized beds.

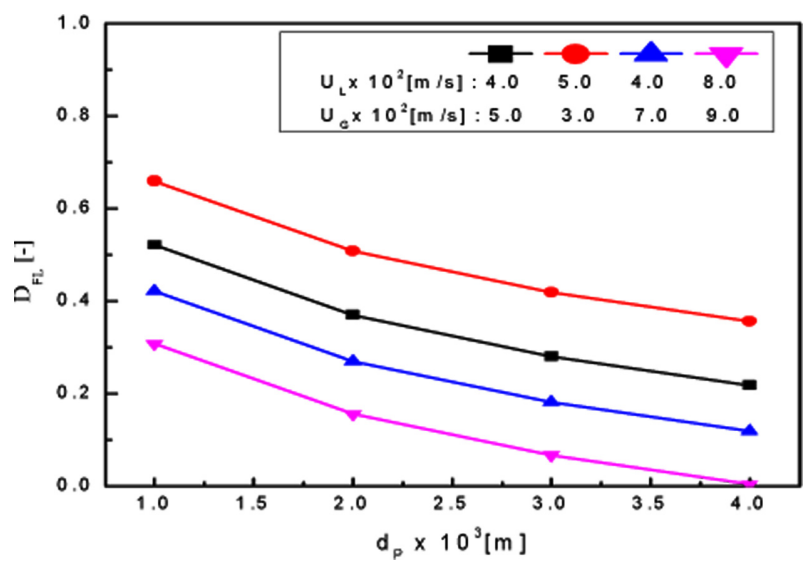

Fig. 9. Effects of particle size on the scale factor, $D_{F L}$, based on the liquid holdup in three phase fluidized beds.

규모인자인 $\mathrm{D}_{F L}$ 에 미치는 영향은 Fig. 7에 나타내었다. Fig. 7에서 볼 수 있듯이 $\mathrm{D}_{F L}$ 값은 기체유속이 증가함에 따라 감소하였는데, 식 (6)의 좌변인 액체 체류량비는 1보다 크므로 Fig. 6에서 $\mathrm{U}_{G}$ 의 증가 에 따른 두 종류 유동층에서 액체 체류량 편차가 감소함을 나타낸다. 삼상유동층에서 액체의 유속과 유동입자의 크기변화가 $\mathrm{D}_{F L}$ 값에 미 치는 영향을 Fig. 8과 9에 각각 나타내었다. Fig. 8과 9에서 볼 수 있 듯이 액체의 유속과 고체유동입자의 크기가 증가하면 $\mathrm{D}_{F L}$ 값은 약간 


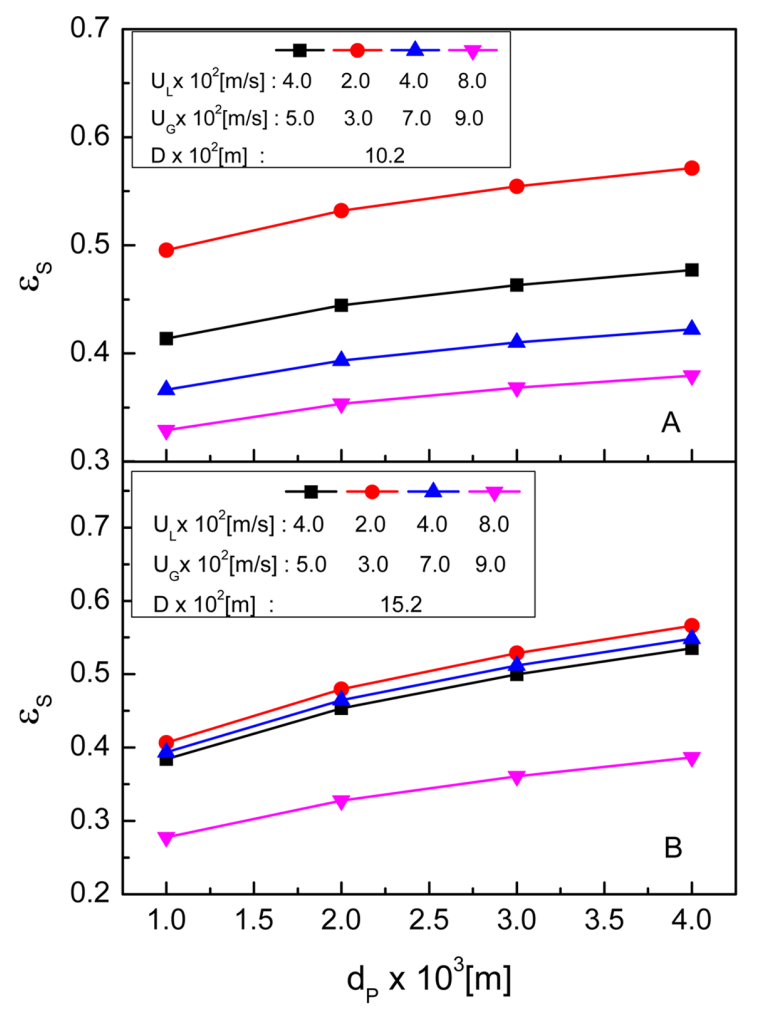

Fig. 10. Effects of particle size on the solid holdup in three phase fluidized beds.

감소하였다. 이는 액체의 유속과 유동입자의 크기가 증가함에 따라 직경이 다른 두 종류의 유동층에서 액체 체류량의 편차가 감소함을 나타낸다. 이와 같은 규모인자 $\mathrm{D}_{F L}$ 의 기체와 액체의 유속 그리고 고 체유동입자의 크기에 대한 의존성은 식 (7)과 같은 상관식으로 나타 낼 수 있었으며, 식 (7)의 상관계수는 0.86이었다. 식 (6)에서 상수 $\mathrm{A}_{L}$ 값은 운전변수인 기체와 액체의 유속 그리고 유동고체입자의 크기가 변화하여도 일정한 상수 값 0.98 을 나타내었다.

$$
\mathrm{D}_{F L}=2.41 \mathrm{U}_{G}^{-0.72} \mathrm{U}_{L}^{-0.32} \mathrm{~d}_{P}^{-097}
$$

삼상유동층에서 유동입자의 크기가 분산상으로 존재하는 고체입 자의 체류량에 미치는 영향을 Fig. 10에 나타내었는데, 유동입자의 크기가 증가함에 따라 입자의 체류량은 점점 증가하였다. 운전변수 가 고체 체류량편차에 미치는 영향을 수식으로 나타내기 위하여 고 체 체류량을 매개로 한 식 (8)과 같은 관계식을 구성하였다.

$$
\frac{\varepsilon_{s 2}}{\varepsilon_{s 1}}=\mathrm{A}_{S}\left(\frac{\mathrm{D}_{2}}{\mathrm{D}_{1}}\right)^{D_{F S}}
$$

삼상유동층 공정에서 기체의 유속이 규모인자 $\mathrm{D}_{F S}$ 에 미치는 영향 을 Fig. 11에 나타내었다. Fig. 11 에서 $\mathrm{D}_{F S}$ 값은 기체의 유속이 증가 함에 따라 감소하였다. 이는 식 (8)의 좌변이 1 보다 작으므로 기체의 유속이 증가함에 따라 고체 체류량의 편차가 증가함을 알 수 있다. 삼상유동층 공정에서 액체의 유속과 유동입자의 크기가 $\mathrm{D}_{F S}$ 에 미치 는 영향을 각각 Fig. 12와 13에 나타내었다. Fig. 12와 13에서 볼 수 있듯이 $\mathrm{D}_{F S}$ 값은 액체의 유속이 증가함에 따라 증가하였으나 유동고 체입자의 크기가 증가함에 따라 감소하였다. 이와 같은 결과는 액체

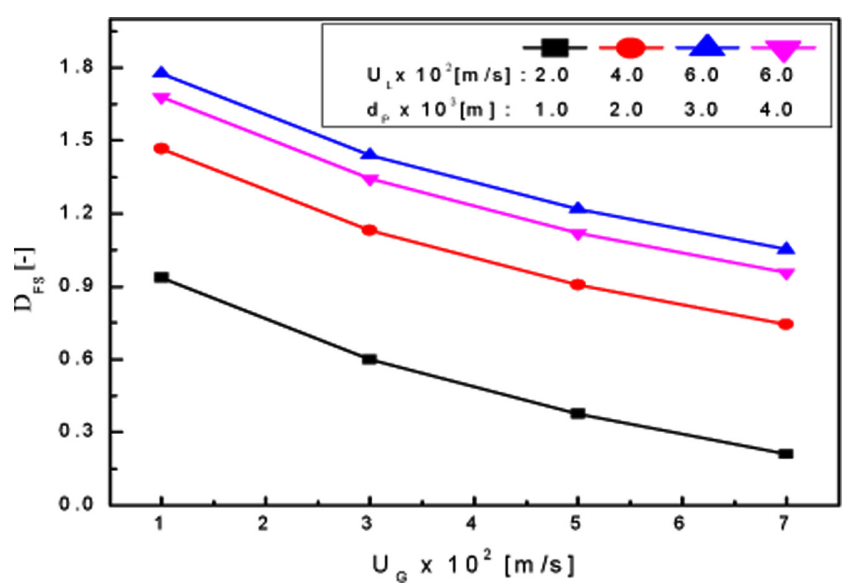

Fig. 11. Effects of gas velocity on the scale factor, $D_{F S}$, based on the solid holdup in three phase fluidized beds.

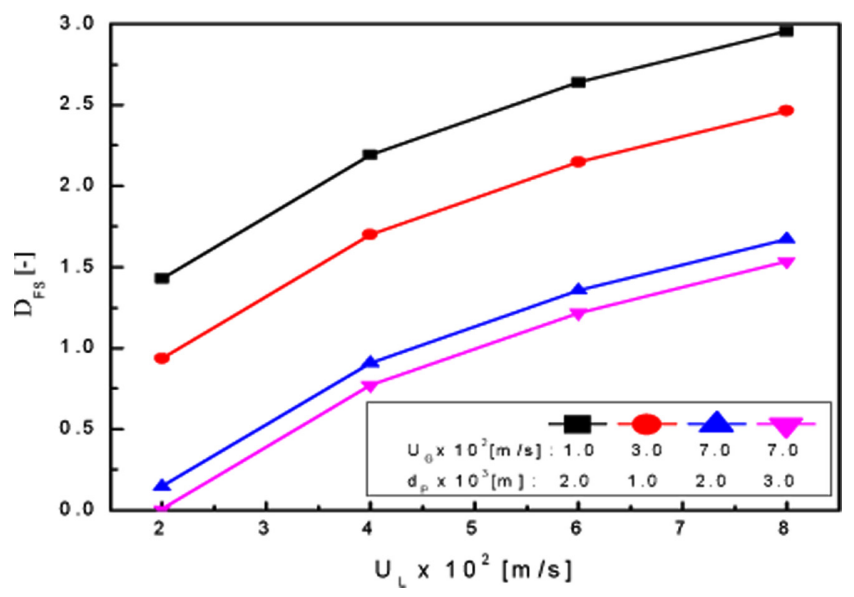

Fig. 12. Effects of liquid velocity on the scale factor, $D_{F S}$, based on the solid holdup in three phase fluidized beds.

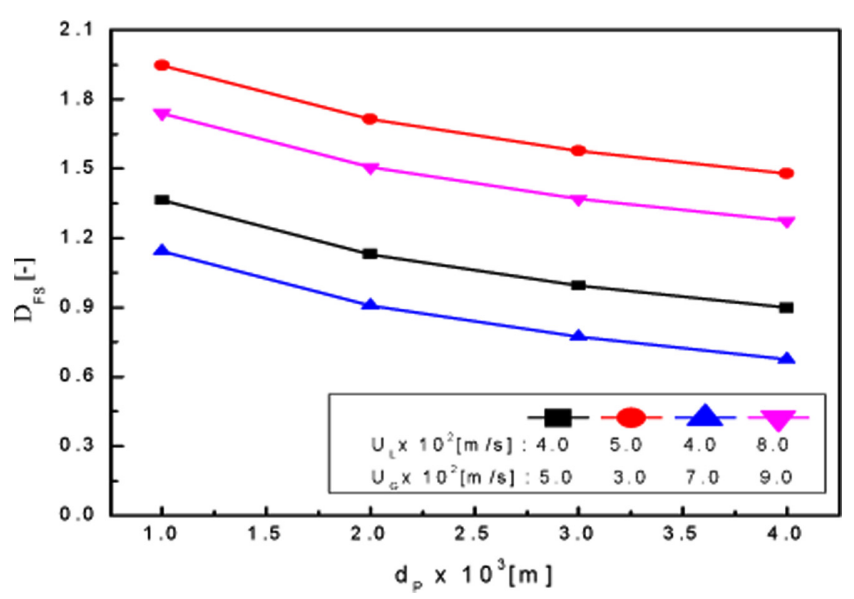

Fig. 13. Effects of particle size on the scale factor, $D_{F S}$, based on the solid holdup in three phase fluidized beds.

유속이 증가하면 직경이 다른 두 종류 유동층에서 고체 체류량의 편 차가 감소하나 유동입자의 크기가 증가하면 고체 체류량의 편차가 증가함을 나타낸다. 이와 같은 규모인자 $\mathrm{D}_{F S}$ 와 운전변수인 기체 및 액체의 유속, 그리고 고체유동입자의 크기의 상관성은 식 (9)와 같은 상관식으로 나타낼 수 있었으며, 상관계수는 0.83 이었다. 식 (8)에서 
비례상수 $\mathrm{A}_{S}$ 는 운전변수인 기체 및 액체의 유속 그리고 고체유동입 자의 크기가 변화하여도 일정한 상수 값 0.59 를 나타내었다.

$$
\mathrm{D}_{F S}=0.29 \mathrm{U}_{G}^{-0.53} \mathrm{U}_{L}^{1.59} \mathrm{~d}_{P}^{-0.51}
$$

\section{3-2. 유체의 단위면적당 유효 부피 흐름(effective volumetric} flux of fluid) 기준의 규모인자

삼상 유동층에서 유체의 흐름은 연속상인 액상과 분산상인 기포 의 흐름으로 구성되기 때문에 유체의 복합적인 흐름속도를 기체와 액체상의 단위면적당 유효부피흐름으로 효과적으로 나타낼 수 있다 [8,14]. 삼상유동층에서 연속적으로 유입되고 유출되는 유체의 유효 부피흐름에 대한 정보는 삼상유동층의 성능과 특성을 결정하는데 매 우 중요한 요소이므로 수력학적 유사성의 고찰에서도 중요한 인자가 될 수 있다.

삼상유동층에서 유체의 단위면적당 유효 부피흐름속도는 Kang과 $\mathrm{Kim}$ 식 $[8,14]$ 에 의해 결정하였다. 즉, 삼상유동층에서 유체의 단위면 적당 유효 부피흐름 속도 $\left(\mathrm{u}_{f}\right)$ 는 식 $(10)$ 과 같이 나타낼 수 있으며 이 는 삼상유동층의 공극률(bed porosity)과 식 (11)과 같은 관계식으로 나타낼 수 있다.

$$
\begin{aligned}
\mathrm{U}_{f} & =\mathrm{f}_{G} \mathrm{U}_{G}+\mathrm{f}_{L} \mathrm{U}_{L} \\
\mathrm{U}_{f} & =\mathrm{K}\left(\varepsilon_{G}+\varepsilon_{L}\right)^{n}
\end{aligned}
$$

식 (10)에서 $\mathrm{f}_{G}$ 와 $\mathrm{f}_{L}$ 은 각각 유체 내에서 기체와 액체상의 분율로 다 음과 같이 정의되며, 식 (11)에서 $\mathrm{K}$ 와 $\mathrm{n}$ 은 각각 상수이다.

$$
\mathrm{f}_{G}=\frac{\varepsilon_{G}}{\varepsilon_{G}+\varepsilon_{L}}, \mathrm{f}_{L}=\frac{\varepsilon_{L}}{\varepsilon_{G}+\varepsilon_{L}}
$$

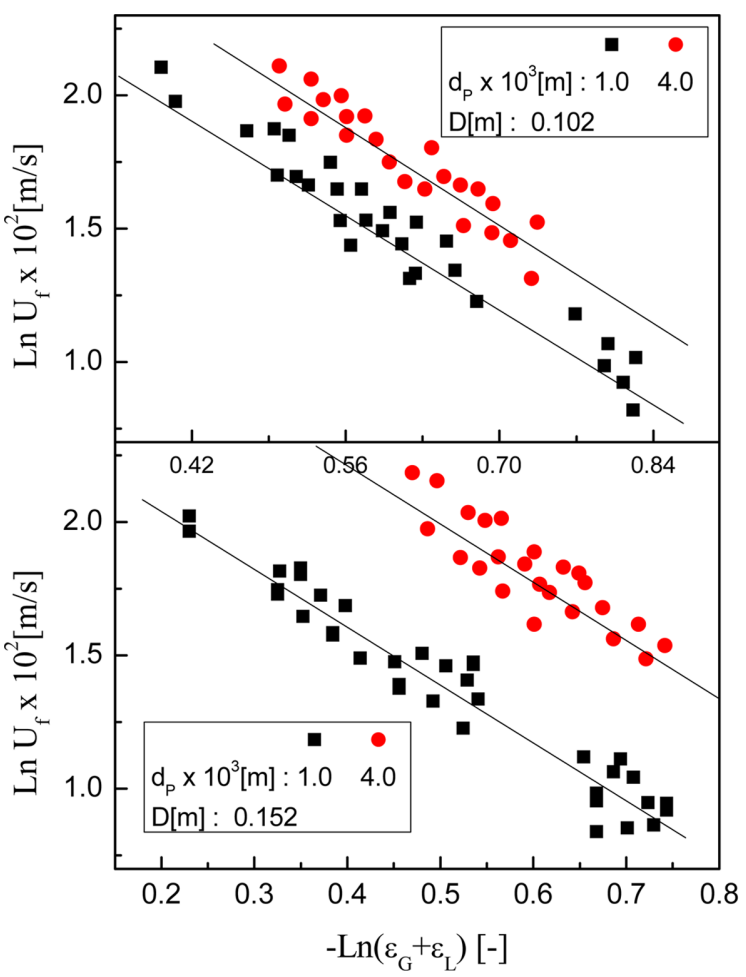

Fig. 14. Relationship between the bed porosity and the effective volumetric flux of fluid in three phase fluidized beds.
삼상유동층에서 Kang과 $\mathrm{Kim}$ 의 식 $[8,14]$ 에 의한 유체의 유효부피흐 름속도와 층공극률의 관계를 Fig. 14에 나타내었는데, 본 연구의 실 험결과도 Kang과 $\mathrm{Kim}$ 의 식에 의해 잘 나타낼 수 있었다.

한편, 본 연구의 실험에서 직경이 $0.102 \mathrm{~m}$ 와 $0.152 \mathrm{~m}$ 의 두 삼상유 동층에서 얻은 유체의 유효 부피흐름 속도를 매개로 한 규모인자 (Scaling factor)를 얻기 위해 두 유동층에서 얻은 유효부피흐름속도 의 비를 유동층 직경의 비와 식 (13)와 같은 관계식을 구성하였다.

$$
\frac{\mathrm{U}_{f 2}}{\mathrm{U}_{f 1}}=\mathrm{A}_{U}\left(\frac{\mathrm{D}_{2}}{\mathrm{D}_{1}}\right)^{D_{F U}}
$$

직경이 서로 다른 두 종류의 삼상유동층에서 얻은 유체의 유효부 피흐름속도 $\left(\mathrm{u}_{f}\right)$ 를 매개로 한 규모인자인 $\mathrm{D}_{F U}$ 값의 운전변수인 기체 와 액체의 유속변화 그리고 유동입자 크기에 의존성을 Fig. 15 17 에 나타내었다. Fig. 15 17에서 볼 수 있듯이 $\mathrm{u}_{f}$ 를 매개로 한 규모인 자는 기체유속이 증가함에 따라 감소하였고 액체의 유속이 증가함에 따라 증가하였으며 고체유동입자의 크기가 증가함에 따라 약간 감소 하였다. 이는 직경이 다른 두 종류의 삼상유동층 내부에서 단위면적 당 유효부피흐름속도비의 편차가 기체와 액체의 유속 그리고 유동입 자의 크기가 변화함에 따라 변화함을 나타낸다. 두 종류의 삼상유동 층에서 직경의 변화가 $\mathrm{u}_{f}$ 에 미치는 영향은 주어진 조건에서 각 상의

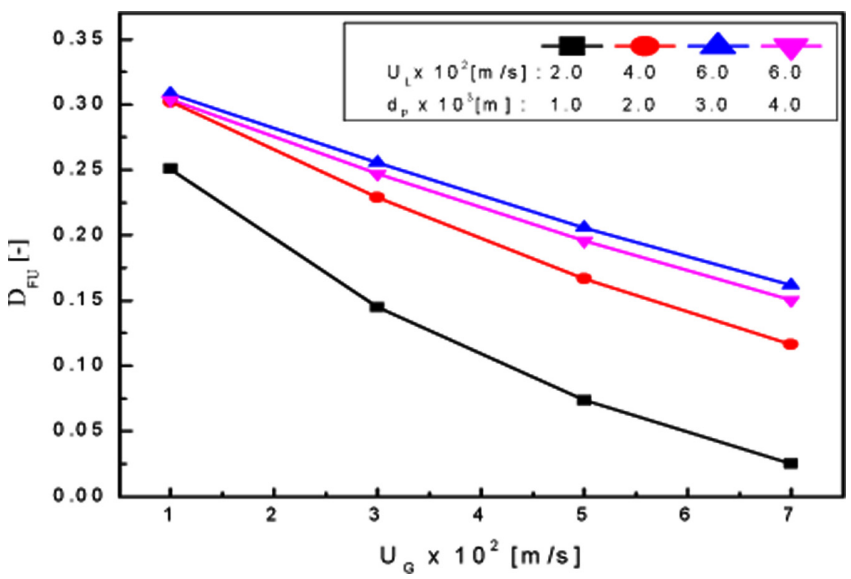

Fig. 15. Effects of gas velocity on the scale factor, $D_{F U}$, based on the effective volumetric flux of fluid in three phase fluidized beds.

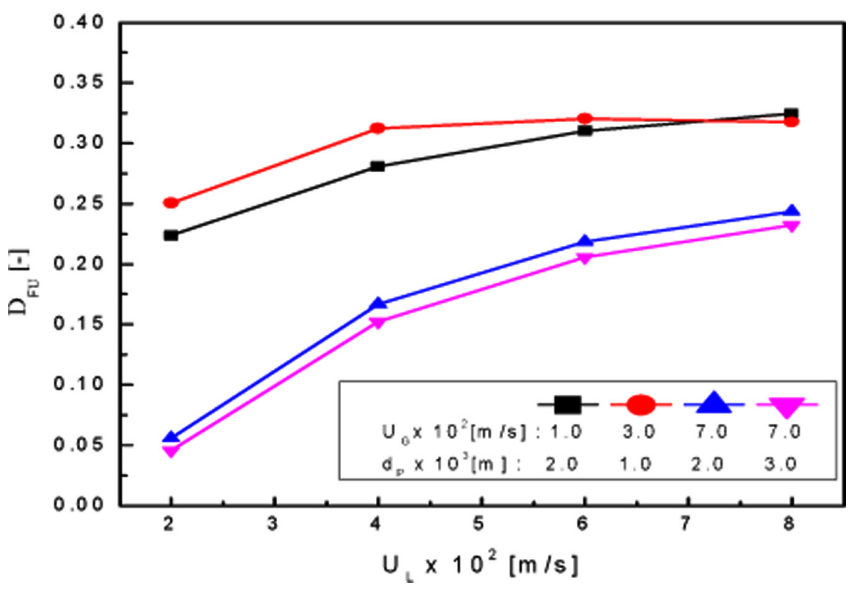

Fig. 16. Effects of liquid velocity on the scale factor, $D_{F U}$, based on the effective volumetric flux of fluid in three phase fluidized beds.

Korean Chem. Eng. Res., Vol. 49, No. 6, December, 2011 


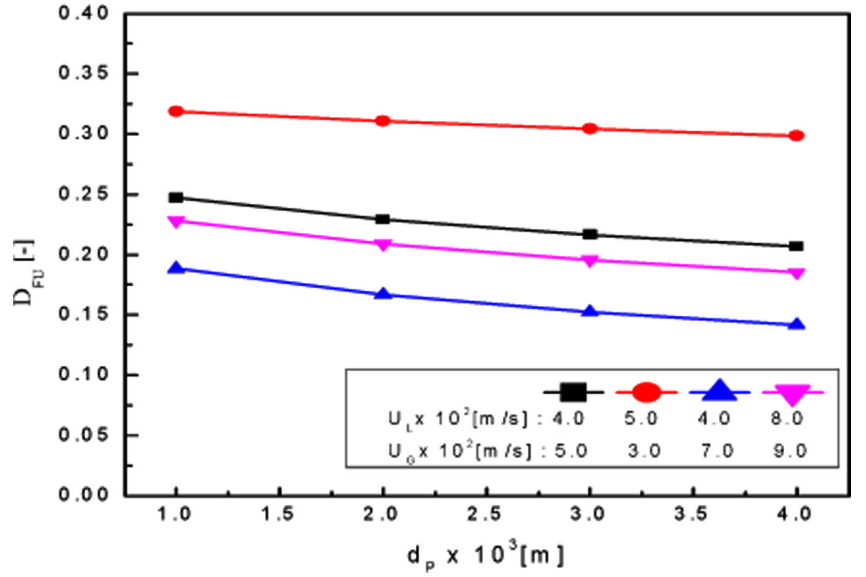

Fig. 17. Effects of particle size on the scale factor, $D_{F U}$, based on the effective volumetric flux of fluid in three phase fluidized beds.

체류량에 따라 변화하므로 식 (13)의 좌변은 1 근처에서 변화하게 되 며 이에 따라 기체와 액체의 유속 그리고 유동입자의 크기 영향도 해 석할 수 있다. 이와 같은 규모인자 $\mathrm{D}_{F U}$ 와 운전변수인 기체 및 액체 의 유속 그리고 고체유동입자의 크기들과의 상관관계는 식(14)와 같 이 나타낼 수 있었으며 상관계수는 0.86 이었다. 식 (13)에서 비례상 수 $\mathrm{A}_{U}$ 는 0.93 으로 운전변수들의 변화에 상관없이 일정한 값을 나타 내었다.

$$
\mathrm{D}_{F U}=0.12 \mathrm{U}_{G}^{-0.41} \mathrm{U}_{L}^{0.80} \mathrm{~d}_{P}^{-0.15}
$$

\section{4. 결 론}

직경이 $0.102 \mathrm{~m}$ 와 0.152 인 두 종류의 삼상유동층에서 기체와 액 체 그리고 유동고체입자의 체류량과 단위면적당 유효부피흐름속도 를 매개로 한 규모인자를 정의하고 검토함으로써 삼상유동층 공정의 수력학적 유사성을 해석할 수 있었다. 직경이 다른 두 삼상유동층에 서 기체 체류량의 편차는 기체와 액체의 유속이 증가함에 따라 감소 하였으나 유동입자의 크기가 증가함에 따라 증가하였다. 직경이 다 른 두 종류 삼상유동층에서 액체 체류량 편차는 기체와 액체 그리고 고체유동입자의 크기가 증가함에 따라 감소하였다. 두 종류 삼상유 동층에서 고체입자 체류량 편차는 기체유속과 유동입자의 크기가 증 가함에 따라 증가하였으나 액체의 유속이 증가함에 따라 감소하였다. 직경이 다른 두 종류 삼상유동층에서 유효부피흐름속도를 매개로 한 규모인자는 기체유속과 유동입자의 크기가 증가함에 따라 감소하였 으나 액체의 유속이 증가함에 따라 증가하였다.

\section{감 사}

본 연구는 2009년도 충남대학교 학술지원비(2009-1626)로 진행되 었으며 이에 감사드립니다.

\section{사용기호}

$$
\begin{array}{ll}
\mathrm{D}_{F} & : \text { Scaling factor } \\
\mathrm{dp} & \text { : particle size[m] }
\end{array}
$$

g : Gravitational acceleration $\left[\mathrm{m} / \mathrm{s}^{2}\right]$

L : Bed height[m]

$\Delta \mathrm{L} \quad$ : Length of test section[m]

$\Delta \mathrm{P} \quad$ : Pressure drop in the test section[Pa.s.]

$\mathrm{S} \quad$ : Cross-sectional area of the column[ $\left.\mathrm{m}^{2}\right]$

U : Velocity $[\mathrm{m} / \mathrm{s}]$

$\mathrm{U}_{f} \quad$ : The effectivity volumetric flux of fluid $[\mathrm{m} / \mathrm{s}]$

W : Weight of solid particles[kg]

\section{아래첨자 \\ G : Gas phase \\ L : : Liquid phase \\ S : Solid phase}

\section{그리이스 문자}

$\varepsilon \quad$ : phase holdup

$\rho_{G} \quad$ : density of gas

$\rho_{L} \quad$ : density of liquid

$\rho_{S} \quad$ : density of solid particle

\section{참고문헌}

1. Fan, L. S., Gas-Liquid-Solid Fluidization Engineering, Butterworths, Stonehair, Ma.(1989).

2. Kim, S. D. and Kang, Y., "Heat and Mass Transfer in Threephase Fluidized Beds; An Overview,' Chem. Eng. Sci., 52(21-22), 3639-3660(1997).

3. Kim, S. D. and Kang, Y., "Hydrodynamic, Heat and Mass Transfer in Inverse and Circulating Three-phase Fluidized-bed Reactors for Waste Water Treatment,' Studies In Surface Science And Catalyst, 159, 103-108(2006).

4. Kang, Y., Lee, K. I., Shin, I. S., Son, S. M., Kim, S. D. and Jung, H., "Characteristics of Hydrodynamics, Heat and Mass Transfer In Three-phase Inverse Fluidized Beds," Korea Chem. Eng. Res. (HWAHHAK KONGHAK), 45, 451(2008).

5. Kim, S. D. and Kang, Y., "Dispersion Phase Characteristics in t Hree-phase Fluidized Beds,' Mixed Flow Hydridynamics, Advanced Eng. Fluid Meckanics Series, Gulf Pub. Co. New York(1996).

6. Wild, G., Saberian, M., Schwarty, J. and Charpentier, J. E., "Gasliquid-solid Fluidized-bed Reactors : State of Art and Industrial Possibilities,' Int'l Chem. Eng., 24, 639(1984).

7. Lefebvre, S., Guy, C. and Chaouki, J., "Solid Phase Hydrodynamics of Three-phase Fluidized Beds-a Convective/dispersive Mixing Model,' Chem. Eng. J. 133(1-3), 85-95(2007).

8. Kang, Y., Ko, M. H., Woo, K. J., Kim, S. D., Park, S. G., Yashima, M. and Fan, L. T., "Mixing of Particles in Gas-liquid-solid Fluidized Beds Containing a Binary Mixture of Particles," I\&EC Res., 37, 4167(1998).

9. Cho, Y. J., Song, P. S., Kim, S. H., Kang, Y. and Kim, S. D., "Stochastic Analysis of Gas-liquid-solid Flow in Three-phase Circulating Fluidized Beds," J. Chem. Eng. Japan., 34(2), 254261(2001)

10. Son, S. M., Shin, H. J., Kang, S. H., Kang, Y. and Kim, S. D., "Characteristic of Phase Holdups and Pressure Fluctuations in a 
Three-phase Swirling Fluidized Bed,' J. Korean Ind. Eng. Chem. 15(6), 652-658(2004).

11. Kang, Y. and Kim, S. D., "Stochastic Analysis and Modeling of Three-phase Fluidized Beds," Chem. Ind. Technol., 13, 27(1995).

12. Lee, K. I., Son, S. M., Kim, U. Y., Kang, S. H., Kang, Y. and Kim, S. D., "Particle Dispersion in Viscous Three-phase Inverse Fluidized Beds," Chem. Eng. Sci., 62, 7060(2007).

13. Son, S. M., Kang, S. H., Kang, Y. and Kim, S. D., "Characteristics of Particle Flow and Heat Transfer in Liquid-particle Swirling Fluidized Beds," Korean Chem. Eng. Res.(HWAHHAK KONGHAK), 44(5), 505-512(2006).

14. Kang, Y. and Kim, S. D., "Solid Flow Transition in Liquid and Three-phase Fluidized Beds,' Particulate Sci. Technol., 6, 133(1988).

15. Shin, K. S., Song, P. S., Lee, C. G. Kang, S. H., Kang, Y., Kim, S. D. and Kim, S. J., "Heat Transfer Coefficient in Viscous Liq- uid-solid Circulation Fluidized Beds,' AIChE J., 51(2), 671-677 (2005).

16. Lin, T. J. and Chiu, H. T., "Effects of Macroscopic Hydrodynamics on Heat Transfer in a Three-phase Fluidized Bed,' Catalysis Today, 79-80, 159-167(2003).

17. Wan, L., Alvareg-cuenca, M., Upreti, S. R. and Lohi, A., "Development of a Three-phase Fluidized Bed Reactor with Enhanced Oxygen Transfer,' Chem. Eng. Processing : Process Intensification, Doi:10.1016/J.Cep. 2009. 10. 012(2009).

18. Ramesh, K. V., Raju, G. M. J., Sarma, G. V. S. and Sarma C. B., "Effect of Internal on Phase Holdups of a Three-phase Fluidized Bed,' Chem. Eng. J. 145, 393(2009).

19. Jena, H. M., Roy, G. K. and Meikap, B. C., "Prediction of Gas Holdup in a Three-phase Fluidized Bed from Bed Pressure Drop Measurement,' Chem. Eng. Res. Des., 86, 1301(2008). 